\title{
Iranian researchers' contributions to research on COVID-19: A bibliometric analysis and visualization
}

\author{
Mohammad Karim Saberi ${ }^{1}$, Arezoo Farhadi $^{1}$, Samira Karami ${ }^{1}$, Heidar Mokhtari*2 (1) \\ Received: 10 Oct 2020 \\ Published: 16 Feb 2021
}

\section{Abstract}

Background: COVID-19 pandemic crisis motivated researchers worldwide to deeply investigate it from different perspectives. As Iran is one of the highly-affected countries by Covid-19, Iranian researchers have focused on studying it. This study aimed at analyzing and visualizing Iranian researchers' papers on COVID-19 from a bibliometric perspective.

Methods: By searching MeSH-selected keywords related to COVID-19 in Scopus, Iranian researchers' papers on COVID-19 were extracted in a CSV format and underwent bibliometric techniques, such as coauthorship analysis, citation, and co-citation analysis, keyword and term co-occurrence mapping and etc. in the Microsoft Excel and VOSviewer software package.

Results: A total of 405 papers were authored by Iranian researchers on COVID-19 during the study period, with the average number of citations per paper of 2.60 and a mean h-index of 15. The majority of papers were original articles in English. Archives of Clinical Infectious Diseases and Archives of Iranian Medicine and Medical Hypotheses were highly ranked publishing journals, respectively. The most productive institute and author were Tehran University of Medical Sciences with 119 papers and Rezaei, N. with 12 papers. Iranian researchers collaborated with the researchers of 73 countries, with the USA ranking first in Covid-19 research, followed by Italy, Canada, and United Kingdom. In publishing papers on COVID-19, Iran ranked first among the Middle Eastern countries and thirteenth internationally.

Conclusion: Iranian researchers were active in 5 main areas of COVID-19 research, including epidemiology, diagnosis, treatment, virology, and systematic review.

Keywords: Bibliometrics, COVID-19, Data visualization, Iran, SARS-CoV-2

Conflicts of Interest: None declared

Funding: The study was funded by the vice-chancellor for Research and Technology, Hamadan University of Medical Sciences (No. 9904242478).

*This work has been published under CC BY-NC-SA 1.0 license.

Copyright $\odot$ Iran University of Medical Sciences

Cite this article as: Saberi MK, Farhadi A, Karami S, Mokhtari H. Iranian researchers' contributions to research on COVID-19: A bibliometric analysis and visualization. Med J Islam Repub Iran. 2021 (16 Feb);35:24. https://doi.org/10.47176/mjiri.35.24

\section{Introduction}

Since its outbreak worldwide, COVID-19 has demonstrated a rapid spread and an increased number of infected cases. The World Health Organization (WHO) reported that COVID-19 spread across 216 countries, areas, or territories in a short time. Globally, there have been 15785 641 confirmed COVID-19 cases, with 640.016 deaths on

Corresponding author: Dr Heidar Mokhtari, h.mokhtari@pnu.ac.ir

1. Department of Medical Library and Information Sciences, School of Paramedicine, Hamadan University of Medical Sciences, Hamadan, Iran

2. Department of Library and Information Science, Payame Noor University, Tehran, Iran
July 26, 2020 (1). Despite its low mortality power in comparison with its 2 family viruses, SAR S and MERS, it causes high mortality (2). This fact has resulted in some fear, anxiety, and mental pressure among people worldwide (3), and COVID-19 has been an urgent public health concern throughout the World (4).

\section{$\uparrow$ What is "already known" in this topic:}

Bibliometric analysis and science visualization are widely used for detecting the intellectual structure of researchers' papers as well as research trends in the publications of journals, institutions, fields, disciplines, and even diseases.

$\rightarrow$ What this article adds:

This study revealed that Iranian researchers did well in research on COVID-19 by making main contributions in various information resources and from different research institutions. They studied COVID-19 from different perspectives and engaged in relatively acceptable international collaboration. 
The COVID-19 global outbreak and pandemic have resulted in the generation of a considerable research body and within only a few months, more than 1000 studies on this topic appeared in the scientific literature (5) as well as more scientific collaboration and ever-increasing production (6), especially in an international level (7). With the crisis influencing all aspects of our life, Covid-19 seems to develop a research trend as a focal point of interest across many scholarly fields (8). However, it needs an increased call of scientific output for reaching better treatments (9). A pandemic publishing change has been observed in which medical journals drastically speed up their publication process for studies on Covid-19 $(10,11)$. Due to the importance and urgency of different studies on all aspects of COVID-19, bibliometrics can deeply study the scientific output on the infection from different bibliometric perspectives and scientometrics indicators.

Bibliometrics is a useful, popular tool and global evaluative discipline that quantitatively evaluates the scholar activity, including the output of many scientific fields and topics. It can be used for evaluating the scientific agents in the level of individual researchers, journals, countries/regions, fields and subfields, etc. In medical science and health care, it may be applied for health policymaking and resource allocation (12).

Visualization is a term originally used in 1 publication by the National Science Foundation (NSF) in 1987. Information visualization makes a user to analyze and interpret a great deal of information. It represents information better and in a huge capacity in the form of illustrations and images, resulting in more understandability and learning (13).

In case of Covid-19, it can be helpful in identifying the past and current status of research and predict future directions and existing gaps (14). Bibliometrics provides researchers and institutions with crucial strategic information for the promotion of their research outcomes, especially in current worldwide pandemic, ie, COVID-19 (15).

Some bibliometric studies have been done on COVID19, and the main studies cover the following topics: general and relatively all-inclusive bibliometric studies (1618); bibliometric study on the global research on Covid-19 (19); Covid-19 global focused topics (20) and co-occurred keywords (21); its medical-related evidence (22); research trends in Covid-19 and in other emerging viral infections (23-25); its global research output indexed in Dimensions database (26) and that of Web of Science (27, 28); COVID-19 early published literature (29); long-term historical and/or bibliometrics study on Covid-19 (17, 3032 ); more productive and influential agents in research on COVID-19 (33), including countries (34); and visualization on its research $(35,36)$. Few studies investigated the contribution of individual countries or regions in this regard (Eg, India (37) and Latin America (38)). Investigating the role of each country in COVID-19 research can inform the role of each country and needed requirements and potential gaps and strengths. As Iran is one of the main COVID-19-affected countries (39), no bibliometric study has been done specifically on the contribution made by Iranian researchers. This study aimed to address this knowledge gap.

\section{Methods}

\section{Databases used}

Researchers can use various prestigious databases for conducting bibliometric studies and science visualization, including among others, Google Scholar, Scopus, and Web of Science (WoS). We used the well-known database, Scopus (Elsevier BV Company, USA) as one of the main and commonly used comprehensive reference databases for bibliometric studies in different fields (40). It is regarded as the world's largest abstract and citation database that researchers regularly use in their various bibliometric studies Some functions of the Scopus facilitate bibliometric analysis, including arranging publications based on their number of citations, publishing date, country, author, journal, or research institution (41). It counts citation numbers for any set of documents as well as measures the Hirsh-index (h-index) as a scientific impact indicator for any set of documents.

\section{Keywords and search strategy}

The main keyword of this study was COVID-19. To make a complete and accurate search, the synonyms of the keywordwas extracted from MeSH (Medical Subject Headings), which is the National Library of Medicine controlled vocabulary thesaurus for indexing papers. Then, the following search query was used for retrieving related papers:

(TITLE-ABS-KEY ( "2019 novel coronavirus disease" ) OR TITLE-ABS-

KEY ( "COVID19" ) OR TITLE-ABS-KEY ( "COVID19 pandemic" ) OR TITLE-ABS-KEY ( "SARS-CoV-2 infection" ) OR TITLE-ABS-KEY ( "COVID-19 virus disease" ) OR TITLE-ABS-KEY ("2019 novel coronavirus infection" ) OR TITLE-ABS-KEY ( "2019-nCoV infection" ) OR TITLE-ABS-KEY ( "coronavirus disease 2019" ) OR TITLE-ABS-KEY ( "coronavirus disease19" ) OR TITLE-ABS-KEY ( "2019-nCoV disease" ) OR TITLE-ABS-KEY ( "COVID-19 virus infection" ) ) AND PUBYEAR > 2018

After retrieving the papers on COVID-19 published around the World and the Middle Eastern countries, we limited the search to Iran.

To avoid bias due to daily updating in the database, data were retrieved from Scopus on a certain day (July 17, 2020). All Iranian researchers' papers on COVID-19 indexed in Scopus were considered without any language limitation from December 1, 2019 to July 17, 2020.

\section{Bibliometric indicators and visualization techniques}

Citation analysis was used in this bibliometric study with a focus on the document type and language, high productive journals, authors and research institutes, highly cited papers on COVID-19. Using some visualization techniques, the co-authorship map of Iranian researchers, the co-occurrence map of the most frequently used keywords and terms, and the co-citation map of the sources were depicted. 
Note that the analysis of co-authorship focuses mainly on the authors and their affiliations to explore social structure and collaborative networks. The co-occurrence analysis considers the most important words or keywords used in documents, making a field of research to be conceptually structured. It helps to understand the underlying patterns of the document set under study. Finally, the cocitation analysis considers the co-cited documents and their relations, especially their possible subject similarity.

\section{Statistical Analysis}

We used the Microsoft Excel 2019 software for bibliometric analysis and VOSviewer software (version 1.6.13) (42) for scientific visualization.

\section{Results}

\section{General data}

In total, 405 papers authored by Iranian researchers on CVID-19 were indexed in the Scopus database. They received 1057 citations, with the mean rate of 2.60 citations per paper. The h-index of the papers was 15 . The majority of papers $(n=170 ; 41.98 \%)$ were original research articles, followed by letter to editors $(\mathrm{n}=119 ; 29.38 \%)$, reviews $(\mathrm{n}=80 ; 19.75 \%)$, notes $(\mathrm{n}=18 ; 4.44 \%)$, editorials $(\mathrm{n}=17 ; 4.20 \%)$, and short surveys $(\mathrm{n}=1 ; 0.25 \%)$. Most papers were in English $(\mathrm{n}=399 ; 98.52 \%)$, followed by Persian $(\mathrm{n}=5 ; 1.23 \%)$ and French $(\mathrm{n}=1 ; .25 \%)$.

Top journals publishing Iranian researchers' papers on COVID-19

Table 1 shows the top 20 journals publishing papers authored by Iranian researchers on COVID-19. In total, 121 papers $(29.88 \%)$ were published in these journals, of which, 14 were in Q1 and Q2 journal ranks. Approximately $3.21 \%(n=13)$ of COVID-19 papers were published in the Archives of Clinical Infectious Diseases as the firstranked journal, followed by the Archives of Iranian Medi- cine $(\mathrm{n}=12 ; 2.96 \%)$, and the Medical Hypotheses $(\mathrm{n}=$ $12 ; 2.96 \%)$. Approximately $3.21 \%(\mathrm{n}=13)$ of COVID-19 papers were published in the Archives of Clinical Infectious Diseases, followed by Archives of Iranian Medicine $(n=12,2.96 \%)$, and Medical Hypotheses $(n=12 ; 2.96 \%)$.

Top Iranian research institutions highly productive in publishing papers on COVID-19

Table 2 shows the top 10 Iranian research institutes highly-productive in publishing papers on COVID-19. The first to third ranks belonged to Tehran University of Medical Sciences $(\mathrm{n}=119 ; 29.38 \%)$, Shahid Beheshti University of Medical Sciences $(\mathrm{n}=77 ; 19.01 \%)$, and Iran University of Medical Sciences $(n=64 ; 15.80 \%)$, respectively. However, when considering the average number of citations per paper (as the influence or quality indicator), the first to the third ranks belonged to Shiraz University of Medical Sciences (4.54), National Research Institute of Tuberculosis and Lung Disease (3.94), and Shahid Beheshti University of Medical Sciences (3.79), respectively. Six $(60 \%)$ of these institutes are located in Tehran.

Top Iranian researchers highly productive in publishing papers on COVID-19

Table 3 shows top Iranian researchers who were highlyproductive (with at least 5 papers) in publishing papers on COVID-19. As can be seen, Rezaei, N with 12 papers ranked first. Four authors each with 6 papers and 10 authors each with 5 papers ranked the second and third, respectively. Considering the average number of citations per paper, Tabarsi, P (8.40) was in the first rank, followed by Badrfam, R and Zandifar, A (8.33), and Simforoosh, N (6.00). Also, 15 authors $(73.33 \%)$ were affiliated to universities located in Tehran.

\section{Co-authorship map}

Iranian researchers co-authored with the authors of 73

Table 1. Top Journals Publishing Iranian Researchers' Papers on COVID-19

\begin{tabular}{|c|c|c|c|c|c|c|c|}
\hline \multirow[t]{2}{*}{ No. } & \multirow[t]{2}{*}{ Journal } & \multicolumn{2}{|c|}{$\begin{array}{l}\text { Documents } \\
(\mathrm{N}=405)\end{array}$} & \multirow[t]{2}{*}{$\begin{array}{c}\text { h-index } \\
2019\end{array}$} & \multirow[t]{2}{*}{$\begin{array}{l}\text { SNIP } \\
2019 \\
\end{array}$} & \multirow[t]{2}{*}{ SJR 2019} & \multirow[t]{2}{*}{ Quartile } \\
\hline & & $\mathrm{n}$ & $\%$ & & & & \\
\hline 1 & Archives of Clinical Infectious Diseases & 13 & 3.21 & 11 & 0.454 & 0.236 & Q3 \\
\hline 2 & Archives of Iranian Medicine & 12 & 2.96 & 45 & 0.713 & 0.472 & Q2 \\
\hline 3 & Medical Hypotheses & 12 & 2.96 & 83 & 0.509 & 0.427 & Q3 \\
\hline 4 & Infection Control and Hospital Epidemiology & 10 & 2.47 & 134 & 1.358 & 1.555 & Q1 \\
\hline 5 & Multiple Sclerosis and Related Disorders & 9 & 2.22 & 30 & 1.014 & 0.829 & Q2 \\
\hline 6 & Asian Journal of Psychiatry & 8 & 1.98 & 29 & 1.022 & 0.736 & Q2 \\
\hline 7 & Archives of Medical Research & 5 & 1.23 & 76 & 0.76 & 0.755 & Q2 \\
\hline 8 & Medical Journal of The Islamic Republic of Iran & 5 & 1.23 & 16 & 0.699 & 0.268 & Q3 \\
\hline 9 & New Microbes and New Infections & 5 & 1.23 & 21 & 0.602 & 0.543 & Q3 \\
\hline 10 & Science of The Total Environment & 5 & 1.23 & 224 & 1.977 & 1.661 & Q1 \\
\hline 11 & Dermatologic Therapy & 4 & 0.99 & 63 & 0.883 & 0.583 & Q2 \\
\hline 12 & International Immunopharmacology & 4 & 0.99 & 106 & 1.049 & 0.992 & Q1 \\
\hline 13 & Iranian Journal of Medical Sciences & 4 & 0.99 & 23 & 1.025 & 0.447 & Q3 \\
\hline 14 & Iranian Journal of Public Health & 4 & 0.99 & 31 & 0.742 & 0.318 & Q3 \\
\hline 15 & Journal of Cellular Physiology & 4 & 0.99 & 167 & 1.186 & 1.267 & Q1 \\
\hline 16 & Journal of Medical Virology & 4 & 0.99 & 111 & 0.78 & 0.855 & Q2 \\
\hline 17 & Phytotherapy Research & 4 & 0.99 & 121 & 1.423 & 0.905 & Q2 \\
\hline 18 & Academic Radiology & 3 & 0.74 & 92 & 1.075 & 0.954 & Q1 \\
\hline 19 & Daru Journal of Pharmaceutical Sciences & 3 & 0.74 & 39 & 1.107 & 0.532 & Q2 \\
\hline 20 & Diabetes and Metabolic Syndrome Clinical Research and Reviews & 3 & 0.74 & 29 & 0.982 & 0.672 & Q2 \\
\hline
\end{tabular}


Table 2. Top Iranian Institutions Highly Productive in Publishing Papers on COVID-19

\begin{tabular}{|c|c|c|c|c|c|c|}
\hline \multirow[t]{2}{*}{$\mathrm{SCR}^{*}$} & \multirow[t]{2}{*}{ Institution } & \multicolumn{2}{|c|}{ Documents $(\mathrm{N}=405)$} & \multirow{2}{*}{$\begin{array}{l}\text { Total Citation } \\
\text { (rank) }\end{array}$} & \multirow[t]{2}{*}{ Citations/Paper (rank) } & \multirow{2}{*}{$\begin{array}{l}\text { h-index } \\
\text { (rank) }\end{array}$} \\
\hline & & $\mathrm{N}$ & $\%$ & & & \\
\hline $1^{\text {st }}$ & Tehran University of Medical Sciences & 119 & 29.38 & $280(2)$ & $2.35(6)$ & $9(2)$ \\
\hline $2^{\text {nd }}$ & $\begin{array}{l}\text { Shahid Beheshti University of Medical Sci- } \\
\text { ences }\end{array}$ & 77 & 19.01 & $292(1)$ & $3.79(3)$ & $10(1)$ \\
\hline $3^{\text {rd }}$ & Iran University of Medical Sciences & 64 & 15.80 & $161(4)$ & $2.52(5)$ & $5(4)$ \\
\hline $4^{\text {th }}$ & Shiraz University of Medical Sciences & 37 & 9.14 & $168(3)$ & $4.54(1)$ & $6(3)$ \\
\hline $5^{\text {th }}$ & Tabriz University of Medical Sciences & 29 & 7.16 & $37(8)$ & $1.28(8)$ & $5(4)$ \\
\hline $6^{\text {th }}$ & Baqiyatallah University of Medical Sciences & 26 & 6.42 & $46(7)$ & $1.77(7)$ & $3(6)$ \\
\hline $7^{\text {th }}$ & Mashhad University of Medical Sciences & 22 & 5.43 & $25(9)$ & $1.14(9)$ & $3(6)$ \\
\hline $8^{\text {th }}$ & Isfahan University of Medical Sciences & 18 & 4.44 & $18(10)$ & $1.00(10)$ & $3(6)$ \\
\hline $9^{\text {th }}$ & $\begin{array}{l}\text { National Research Institute of Tuberculosis } \\
\text { and Lung Disease Tehran }\end{array}$ & 16 & 3.95 & $63(5)$ & $3.94(2)$ & $4(5)$ \\
\hline $10^{\text {th }}$ & Children's Medical Center TUMS & 15 & 3.70 & $47(6)$ & $3.13(4)$ & $3(6)$ \\
\hline
\end{tabular}

Table 3. Top Iranian Researchers Highly Productive in Publishing Papers on COVID-19

\begin{tabular}{|c|c|c|c|c|c|c|}
\hline Author's Name & $\begin{array}{c}\text { No. of } \\
\text { Articles }\end{array}$ & $\begin{array}{l}\text { Total Citation } \\
\text { (R) }\end{array}$ & $\begin{array}{l}\text { Citations/Paper } \\
\text { (Rank) }\end{array}$ & $\begin{array}{l}\text { h-index } \\
\text { (R) }\end{array}$ & Affiliation & Author ID \\
\hline Rezaei, N & 12 & 46 & $3.83(4)$ & 3 & $\begin{array}{c}\text { Tehran University of Medical Sciences, } \\
\text { Tehran, Iran }\end{array}$ & 57209784995 \\
\hline Badrfam, R & 6 & 50 & $8.33(2)$ & 2 & $\begin{array}{c}\text { Tehran University of Medical Sciences, } \\
\text { Tehran, Iran }\end{array}$ & 54994198100 \\
\hline Haseli, S & 6 & 16 & $2.67(6)$ & 2 & $\begin{array}{c}\text { Shahid Beheshti University of Medical Sci- } \\
\text { ences, Tehran, Iran }\end{array}$ & 57202386588 \\
\hline Saffaei, A & 6 & 36 & $6.00(3)$ & 1 & $\begin{array}{c}\text { Shahid Beheshti University of Medical Sci- } \\
\text { ences, Tehran, Iran }\end{array}$ & 56429617700 \\
\hline Zandifar, A. & 6 & 50 & $8.33(2)$ & 2 & $\begin{array}{l}\text { Alborz University of Medical Sciences, Karaj, } \\
\text { Iran }\end{array}$ & 57130779000 \\
\hline Aminnejad, R & 5 & 10 & $2.00(7)$ & 1 & $\begin{array}{l}\text { Qom University of Medical Sciences, Qom, } \\
\text { Iran }\end{array}$ & 56721304500 \\
\hline Gholamrezanezhad, A & 5 & 4 & $.80(9)$ & 1 & $\begin{array}{c}\text { Keck School of Medicine of USC, Los Ange- } \\
\text { les, United States }\end{array}$ & 10044363200 \\
\hline Izadi, M & 5 & 5 & $1.00(8)$ & 1 & $\begin{array}{c}\text { Baqiyatallah University of Medical Sciences, } \\
\text { Tehran, Iran }\end{array}$ & 16230256600 \\
\hline Moradi, G & 5 & 3 & $.60(10)$ & 1 & $\begin{array}{c}\text { Kurdistan University of Medical Sciences, } \\
\text { Sanandaj, Iran }\end{array}$ & 48161434000 \\
\hline Naser Moghadasi A. & 5 & 0 & $.00(11)$ & 0 & $\begin{array}{c}\text { Tehran University of Medical Sciences, } \\
\text { Tehran, Iran }\end{array}$ & 55362978300 \\
\hline Sahraian & 5 & 0 & $.00(11)$ & 0 & $\begin{array}{c}\text { Tehran University of Medical Sciences, } \\
\text { Tehran, Iran }\end{array}$ & 55886074600 \\
\hline Shalbafan, M & 5 & 10 & $2.00(7)$ & 2 & $\begin{array}{c}\text { Iran University of Medical Sciences, Tehran, } \\
\text { Iran }\end{array}$ & 56641835000 \\
\hline Tabarsi, P & 5 & 42 & $8.40(1)$ & 1 & $\begin{array}{c}\text { Shahid Beheshti University of Medical Sci- } \\
\text { ences, Tehran, Iran }\end{array}$ & 22954831100 \\
\hline Taheri, M. S & 5 & 19 & $3.80(5)$ & 2 & $\begin{array}{c}\text { Shahid Beheshti University of Medical Sci- } \\
\text { ences, Tehran, Iran }\end{array}$ & 56186823500 \\
\hline Talebi Bezmin Abadi, A & 5 & 5 & $1.00(8)$ & 1 & Tarbiat Modares University, Tehran, Iran & 57194487001 \\
\hline
\end{tabular}

countries in papers on COVID-19. A total of 23 countries coauthored at least 5 papers and were entered for depicting the co-authorship map. As Figure 1 shows, Iranian researchers coauthored with American researchers in writing 70 papers in the first rank. The second and third ranks belonged to Italian researchers with 31 papers and Canadian and English researchers each with 25 papers, respectively.

\section{Iranian researchers' highly cited papers on COVID-19}

Out of 405 papers, 177 (43.7\%) received at least 1 citation. Table 4 shows the bibliographic information on the top 13 papers (including 6 original research articles, 5 reviews, and 2 letters) that received at least 20 citations. The most highly cited paper was authored by Aminian et al (2020) titled as "COVID-19 Outbreak and Surgical Practice: Unexpected Fatality in Perioperative Period" with 55 received citations. Published in one of the influential journals, ie, Annals of Surgery, the paper discusses surgical practice in the initial phase of COVID-19.

\section{Comparing with the Middle Eastern countries}

Table 5 shows the total contribution and rank of the Middle Eastern countries on COVID-19. These countries published 1362 papers on COVID-19. Iran $(n=405$; $29.74 \%)$ and Turkey $(\mathrm{n}=307 ; 22.54 \%)$ ranked first and second in this regard, respectively, and contributed to $52.28 \%$ of the papers authored by the Middle Eastern countries. Other 15 countries contributed to publishing 47.72 papers on COVID-19.

\section{Comparing with other countries}

Table 6 shows the total contribution and the rank of other countries on COVID-19. They published 25327 papers on COVID-19. The United States $(\mathrm{n}=4503 ; 17.78 \%)$, China $(\mathrm{n}=2998 ; 11.84 \%)$, and Italy $(\mathrm{n}=2078 ; 8.20 \%)$ ranked first to third in this regard. Other 15 countries contributed to publishing 47.72 papers on COVID-19, and only 2 Middle Eastern countries (Iran in the $13^{\text {th }}$ rank and Turkey in the $16^{\text {th }}$ rank) were among the World's top 20 countries. 


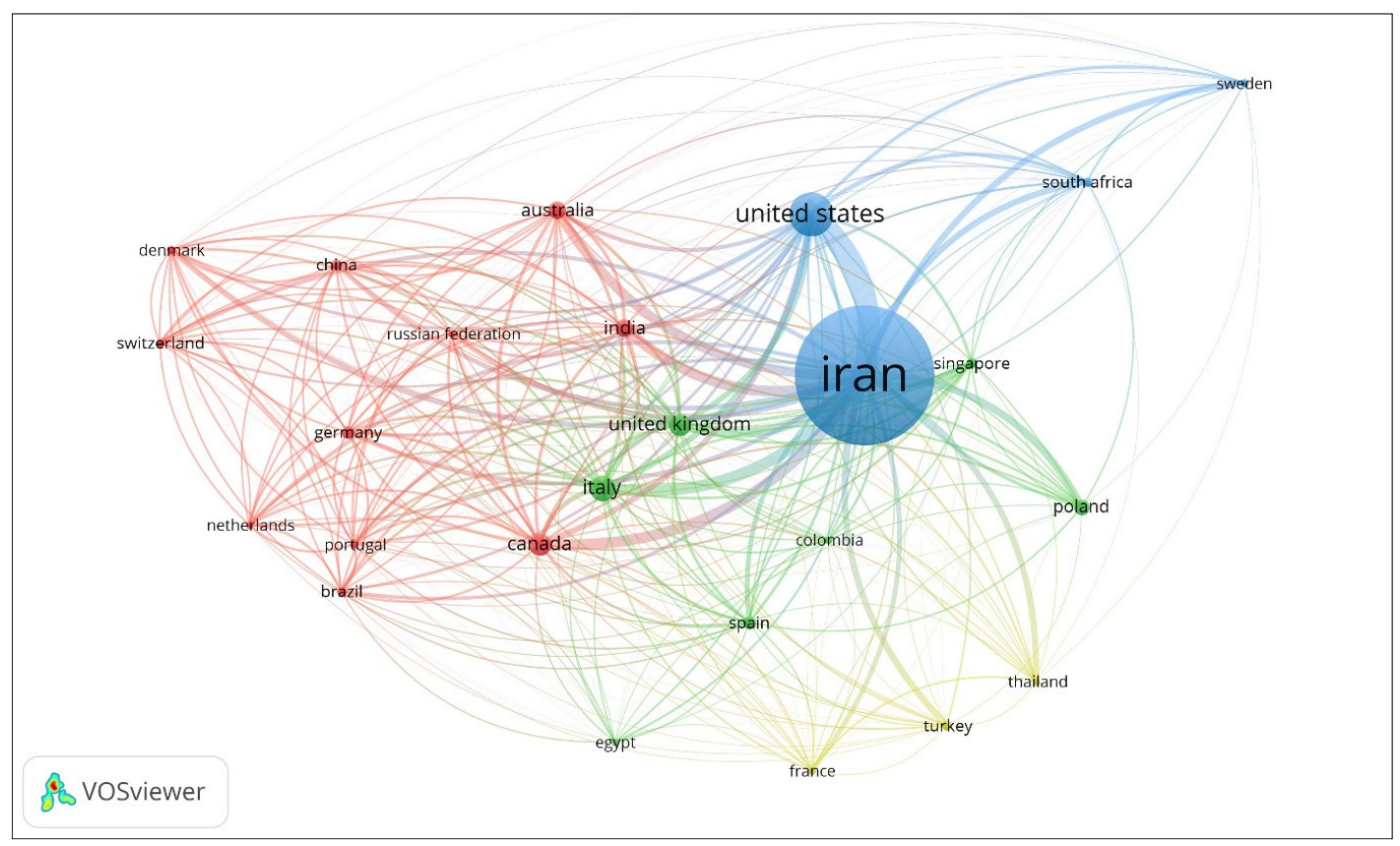

Fig. 1. Co-authorship Map of Countries That co-authored with Iran on COVID-19

Table 4. Top Highly Cited Papers Published by Iranian Researches on COVID-19

\begin{tabular}{|c|c|c|c|c|c|c|}
\hline $\mathrm{R}$ & Authors & Title & Year & Source title & $\begin{array}{c}\text { Cited } \\
\text { by }\end{array}$ & Doc type \\
\hline 1 & Aminian, A et al & $\begin{array}{l}\text { COVID-19 Outbreak and Surgical Practice: Unex- } \\
\text { pected Fatality in Perioperative Period }\end{array}$ & 2020 & Annals of surgery & 55 & Article \\
\hline 2 & $\begin{array}{l}\text { Asadi-Pooya A A and } \\
\text { Simani L. }\end{array}$ & $\begin{array}{l}\text { Central nervous system manifestations of COVID-19: } \\
\text { A systematic review }\end{array}$ & 2020 & $\begin{array}{l}\text { Journal of the Neurolog- } \\
\text { ical Sciences }\end{array}$ & 43 & Review \\
\hline 2 & $\begin{array}{l}\text { Zandifar A and Badr- } \\
\text { fam R }\end{array}$ & Iranian mental health during the COVID-19 epidemic & 2020 & $\begin{array}{l}\text { Asian Journal of Psychi- } \\
\text { atry }\end{array}$ & 43 & Letter \\
\hline 2 & $\begin{array}{l}\text { Habibzadeh P and } \\
\text { Stoneman E K }\end{array}$ & The novel coronavirus: A bird's eye view & 2020 & $\begin{array}{l}\text { International Journal of } \\
\text { Occupational and Envi- } \\
\text { ronmental Medicine }\end{array}$ & 43 & Review \\
\hline 2 & Malik Y S et al & $\begin{array}{l}\text { Emerging novel coronavirus }(2019-\mathrm{nCoV}) \text { - current } \\
\text { scenario, evolutionary perspective based on genome } \\
\text { analysis and recent developments }\end{array}$ & 2020 & Veterinary Quarterly & 43 & Article \\
\hline 3 & Moein S T et al & Smell dysfunction: a biomarker for COVID-19 & 2020 & $\begin{array}{l}\text { International Forum of } \\
\text { Allergy and Rhinology }\end{array}$ & 41 & Article \\
\hline 4 & Sahraei Z et al & $\begin{array}{l}\text { Aminoquinolines against coronavirus disease } 2019 \\
\text { (COVID-19): chloroquine or hydroxychloroquine }\end{array}$ & 2020 & $\begin{array}{l}\text { International Journal of } \\
\text { Antimicrobial Agents }\end{array}$ & 35 & Article \\
\hline 5 & Dhama $\mathrm{K}$ et al & $\begin{array}{l}\text { COVID-19, an emerging coronavirus infection: ad- } \\
\text { vances and prospects in designing and developing } \\
\text { vaccines, immunotherapeutics, and therapeutics }\end{array}$ & 2020 & $\begin{array}{l}\text { Human Vaccines and } \\
\text { Immunotherapeutics }\end{array}$ & 31 & Review \\
\hline 6 & Karimi-Zarchi M et al & $\begin{array}{l}\text { Vertical Transmission of Coronavirus Disease } 19 \\
\text { (COVID-19) from Infected Pregnant Mothers to } \\
\text { Neonates: A Review }\end{array}$ & 2020 & $\begin{array}{l}\text { Fetal and Pediatric Pa- } \\
\text { thology }\end{array}$ & 26 & Review \\
\hline 7 & $\begin{array}{l}\text { Sharifi-Razavi, A } \\
\text { Karimi N, and Rou- } \\
\text { hani N }\end{array}$ & $\begin{array}{l}\text { COVID-19 and intracerebral haemorrhage: causative } \\
\text { or coincidental? }\end{array}$ & 2020 & $\begin{array}{l}\text { New Microbes and New } \\
\text { Infections }\end{array}$ & 24 & Article \\
\hline 8 & Farnoosh G et al & $\begin{array}{l}\text { Understanding the severe acute respiratory syndrome } \\
\text { coronavirus } 2 \text { (SARS-CoV-2) and coronavirus dis- } \\
\text { ease (COVID-19) based on available evidence - A } \\
\text { narrative review }\end{array}$ & 2020 & $\begin{array}{l}\text { Journal of Military Med- } \\
\text { icine }\end{array}$ & 22 & Review \\
\hline 9 & $\begin{array}{l}\text { Saghazadeh A, and } \\
\text { Rezaei N. }\end{array}$ & $\begin{array}{l}\text { Immune-epidemiological parameters of the novel } \\
\text { coronavirus-a perspective }\end{array}$ & 2020 & $\begin{array}{l}\text { Expert Review of Clini- } \\
\text { cal Immunology }\end{array}$ & 21 & Article \\
\hline 10 & $\begin{array}{l}\text { Takian A, Raoofi A, } \\
\text { and Kazempour- } \\
\text { Ardebili S }\end{array}$ & $\begin{array}{l}\text { COVID-19 battle during the toughest sanctions } \\
\text { against Iran }\end{array}$ & 2020 & The Lancet & 20 & Letter \\
\hline
\end{tabular}

\section{Keyword co-occurrence map}

Iranian researchers used 685 unique keywords in their 405 papers on COVID-19. The keywords with the higher number of occurrences were "Human", "Coronavirus Dis- ease 2019", "COVID-19", "Pandemic", "Virus Pneumonia", "Coronavirus Infection", "Pandemics", "Severe Acute Respiratory Syndrome Coronavirus 2" and "Pneumonia", respectively. Figure 2 depicts the co-occurrence 


\begin{tabular}{|c|c|c|c|c|}
\hline No. & Country & Documents & $\%$ of Total & Rank \\
\hline 1 & Iran & 405 & 29.74 & 1 \\
\hline 2 & Turkey & 307 & 22.54 & 2 \\
\hline 3 & Saudi Arabia & 179 & 13.14 & 3 \\
\hline 4 & Israel & 128 & 9.40 & 4 \\
\hline 5 & Egypt & 109 & 8.00 & 5 \\
\hline 6 & United Arab Emirates & 51 & 3.74 & 6 \\
\hline 7 & Iraq & 31 & 2.28 & 7 \\
\hline 8 & Lebanon & 29 & 2.13 & 8 \\
\hline 9 & Qatar & 29 & 2.13 & 8 \\
\hline 10 & Jordan & 28 & 2.06 & 8 \\
\hline 11 & Oman & 22 & 1.62 & 9 \\
\hline 12 & Cyprus & 19 & 1.40 & 10 \\
\hline 13 & Kuwait & 14 & 1.03 & 11 \\
\hline 14 & Bahrain & 3 & 0.22 & 12 \\
\hline 15 & Yemen & 3 & 0.22 & 12 \\
\hline 16 & Palestine & 3 & 0.22 & 12 \\
\hline 17 & Syrian Arab Republic & 2 & 0.15 & 13 \\
\hline
\end{tabular}

\begin{tabular}{|c|c|c|c|}
\hline Rank & Country & Papers & $\%$ of the Total \\
\hline 1 & United States & 4503 & 17.78 \\
\hline 2 & China & 2998 & 11.84 \\
\hline 3 & Italy & 2078 & 8.20 \\
\hline 4 & United Kingdom & 1998 & 7.89 \\
\hline 5 & India & 1093 & 4.32 \\
\hline 6 & Canada & 767 & 3.03 \\
\hline 7 & France & 753 & 2.97 \\
\hline 8 & Germany & 716 & 2.83 \\
\hline 9 & Australia & 657 & 2.59 \\
\hline 10 & Spain & 646 & 2.55 \\
\hline 11 & Switzerland & 425 & 1.68 \\
\hline 12 & Brazil & 411 & 1.62 \\
\hline 13 & Iran & 405 & 1.60 \\
\hline 14 & Singapore & 355 & 1.40 \\
\hline 15 & Netherlands & 347 & 1.37 \\
\hline 16 & Turkey & 307 & 1.21 \\
\hline 17 & Belgium & 264 & 1.04 \\
\hline 18 & Hong Kong & 259 & 1.02 \\
\hline 19 & Japan & 251 & 0.99 \\
\hline 20 & South Korea & 235 & 0.93 \\
\hline
\end{tabular}

map of the keywords with the minimum co-occurrence of 20. The most highly used keywords were included in 3 main clusters. The first cluster (in red) mainly focuses on epidemiological aspects. The second main cluster (in

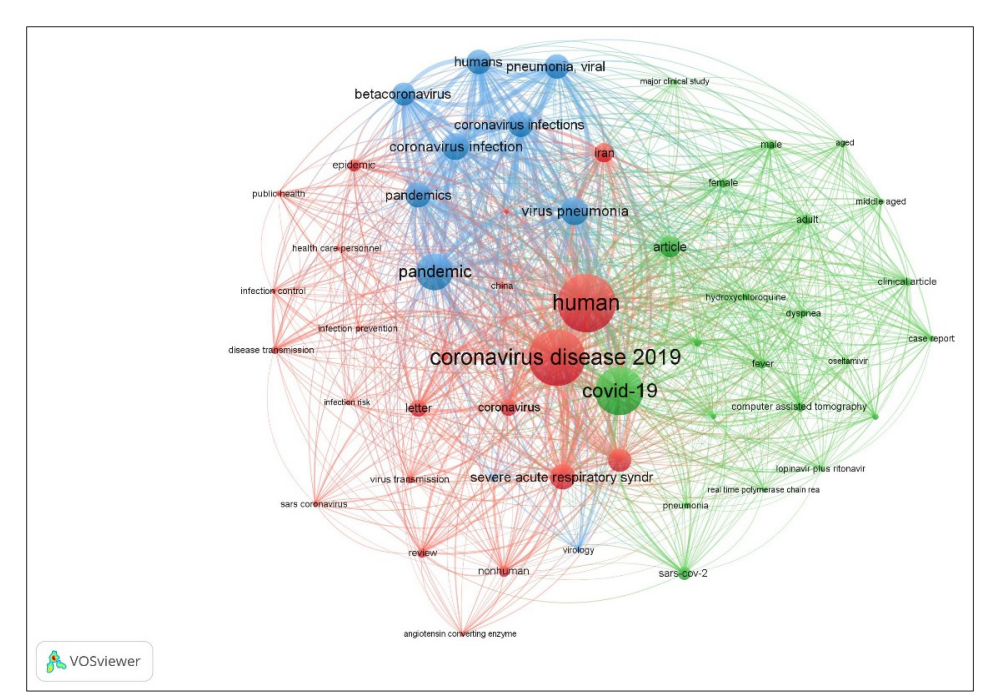

Fig. 2. Keyword Co-occurrence Map of Iranian Researchers' Papers on COVID-19

green) mainly considers the diagnosis and treatment aspects, and the third (in blue) highlights the virology of COVID-19. 


\section{Title /abstract term co-occurrence map}

A total of 6257 terms were extracted from the titles and abstracts of the papers on COVID-19 authored by Iranian researchers. Determining 10 as a threshold, the term cooccurrence map was depicted by terms with at least 10 times of co-occurrences (Fig. 3). The main terms in the first cluster (in red) were fever, lung, inflammation, mechanism, severe acute respiratory syndrome coronavirus 2, and pathogenesis. This cluster can be titled "Pathology of COVID-19." In the second cluster (in green), some terms, such as article, paper, literature, Scopus, PubMed, and systematic review were included and can be named as
"COVID-19 systematic reviews. "The third cluster (in blue) can be titled as "COVID-19 Epidemiology," as some related terms, such as epidemic, mortality rate, Iran, data, model, analysis, year, day, and number can be seen in it.

\section{Co-citation map}

In the papers authored by Iranians on COVID-19, about 3895 documents were cited, including journals, books, etc. for identifying core sources; all 15 sources receiving at least 50 citations were included in the co-citation map. As can be seen in Figure 4, the first to third ranks in receiving citations belonged to the Lancet (425 citations), New Eng-

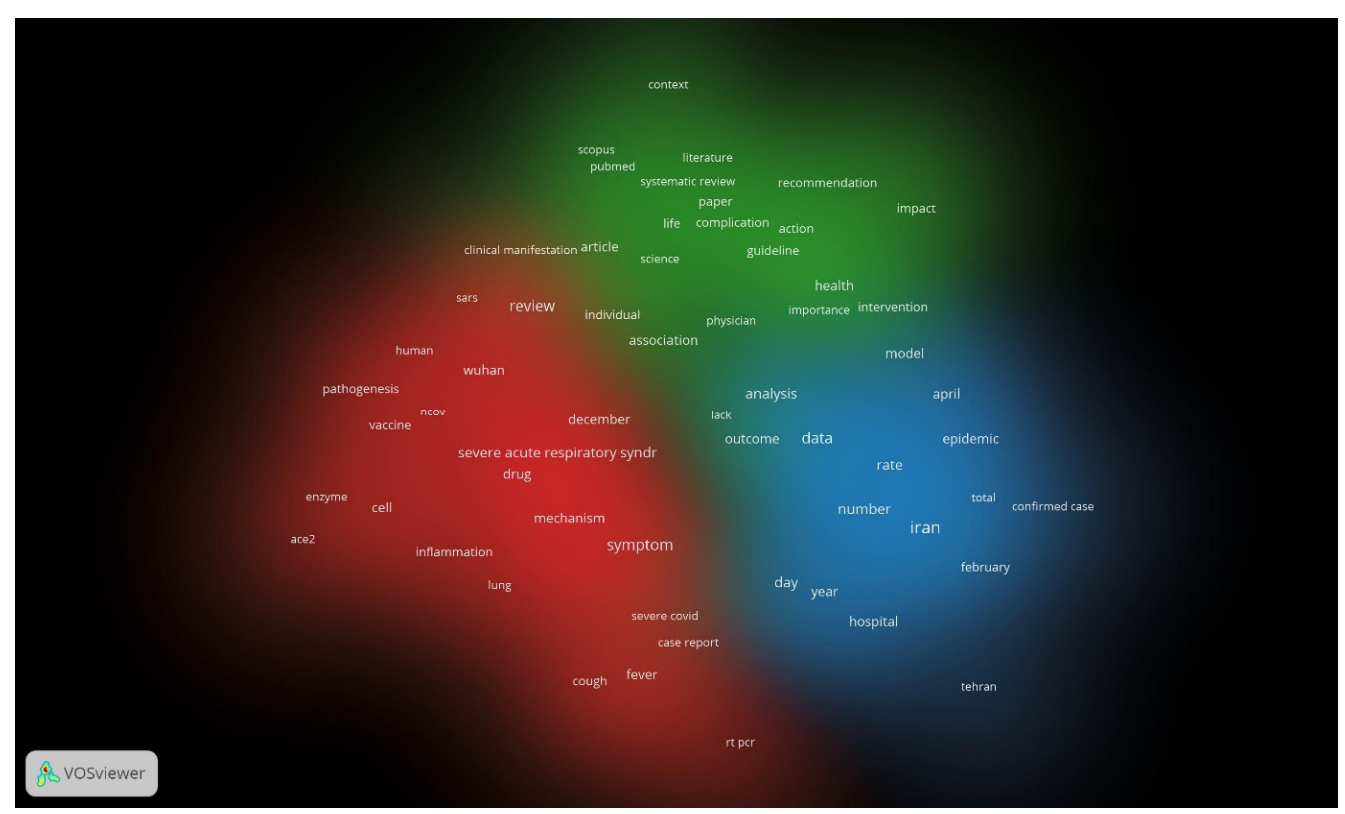

Fig. 3. Title/Abstract Term Co-occurrence Map of Iranian Researchers' Papers on COVID-19

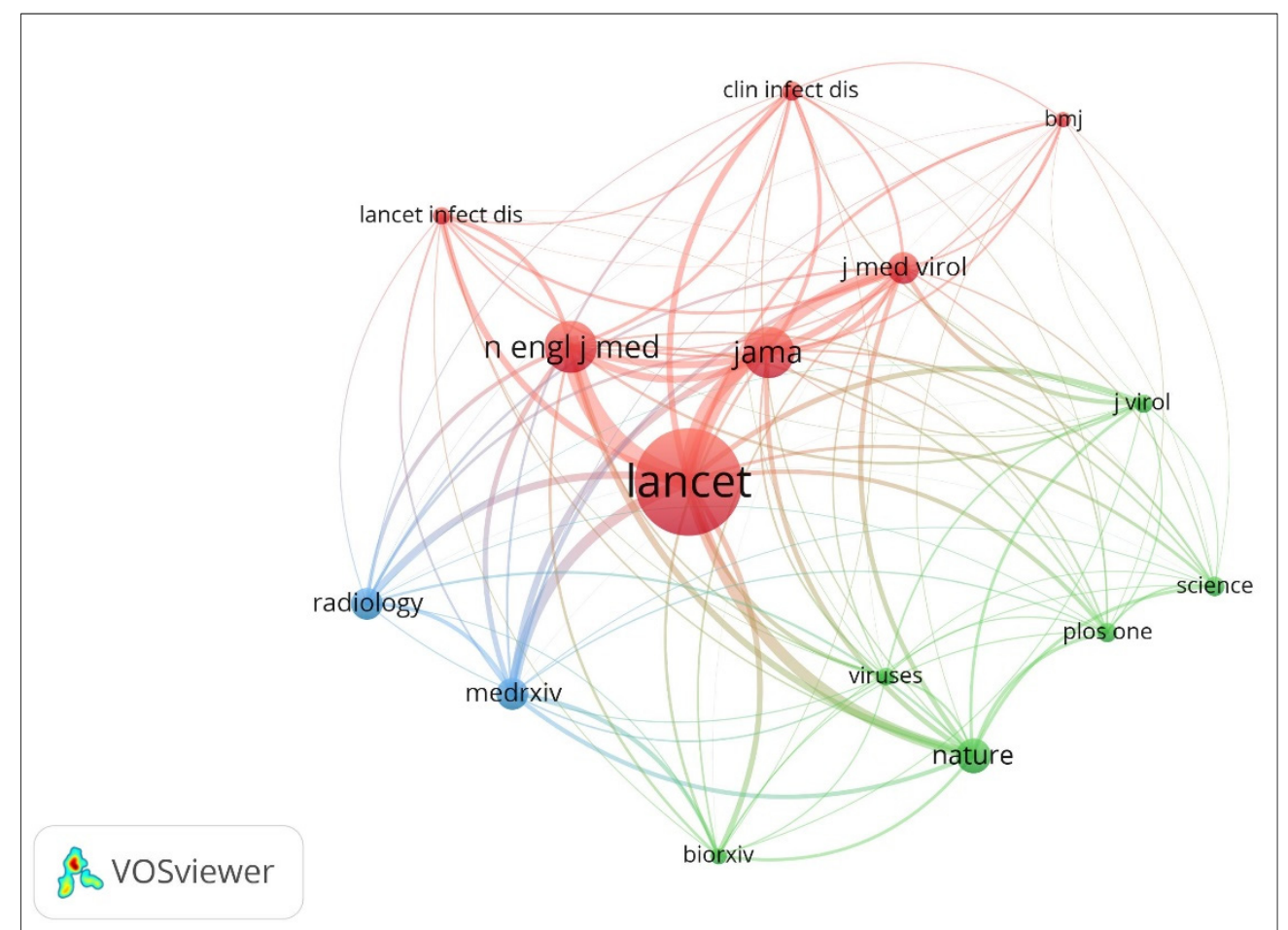

Fig. 4. Co-citation Map of Sources Cited by Iranian Researchers in Their Papers on COVID-19 
land Journal of Medicine (NEJM) (166 citations), and Journal of the American Medical Association (JAMA) (161 citations).

\section{Discussion}

In this bibliometric study, we aimed at investigating Iranian researchers' role in research on COVID-19 by identifying highly productive authors, sources, and research institutes and analyzing their citations and mapping their scientific activities on the topic. We can know evaluate the contribution made by Iranian researches regarding various aspects of COVID-19.

Iranian researchers have contributed considerably in research on COVID-19 in its short time by publishing 405 papers of all types (generally original articles) mostly in prestigious and high impact medical journals and receiving 1507 citations from different related sources. Despite their variety, the contributing authors and universities or research institutions were not countrywide. As the distribution of highly productive and influential ones show, most productive research institutes are located in Tehran and most highly-productive researchers are affiliated to the institutions in Tehran, as the capital city; thus, other institutes and universities in other parts of the country should heavily participate in research on COVID-19.

Iranian researchers more collaborated with European researchers on COVID-19. Iran is ranked first among the Middle Eastern countries, which is notable as the contribution of Asian countries in international research on COVID-19 has been evaluated rather low (24). Despite its high rank among the World, Iran needs to collaborate with Asian countries more than ever to discover and solve local problems related to this crisis. However, as more international collaboration is needed for better understanding of Covid-19 (18) and discovering more efficient solutions (6) by focusing on treatment and vaccination (30), Iranian researchers should collaborate with international scientists to help discover possible solutions. Also, they should consider other underexplored topics, such as mental health problems, employing new techniques for treatment (22), and finding urgent solutions for prevention and control (32).

Iranian researchers considered all main worldwide trends in COVID-19(35) in their studies on COVID-19, including its epidemiology, diagnosis and treatment and virology. These are of hot topics on COVID-19 $(14,36)$. In addition, they cited highly-prestige journals in the medical field such as the Lancet, the New England Journal of Medicine and JAMA, that some proven to be more active in COVID-19 research, such as the Lancet (19).

Countries throughout the World attempt to increasingly participate in research on the COVID-19 pandemic, and Iran is not an exception. A study on the global level perspective of COVID-19 research output during the 1989 and March 2020 in WoS database showed that related publications were published by 127 countries worldwide, including Iran. In line with our findings, USA has been the most productive country on COVID-19 research (27). China had published most of the literatures (35) and as Iran established a close cooperation with USA (43). Irani- an researchers and research institutes should consider that international collaboration with different countries will promote their research on COVID-19, as it is necessary that the global research collaboration among high- and low-middle-income countries in the various stages of the prevention and control of the pandemic be emphasized.

\section{Conclusion}

In conclusion, this study revealed that Iranian researchers did well in research on COVID-19 by making main contributions in various information resources from different research institutions, by investigating COVID-19 from different perspective, and by engaging in international collaboration.

In this study, all scientific publications on COVID-19 were analyzed without making any limitations on paper language and type. Future studies can focus on certain languages (such as Persian) or individual paper types (such as original articles) as well as other countries and regions.

As a limitation of the study, we used only Scopus (Elsevier BV Company, USA) as one of the well-known bibliometric databases. Other comparative studies can be done in other databases, such as Google Scholar, Web of Science (WoS), and PubMed. Studying the relationship between the citation counts of COVID-19 papers and sharing them in social media can be helpful in detecting highly considered and heavily concerned items by the general public.

Finally, our study can inform Iranian research institutes and universities as well as authors about topics with potential for deep study on COVID-19. It also suggests a pattern for further bibliometric studies on the topic for individual countries.

\section{Acknowledgement}

The study was funded by the vice-chancellor for Research and Technology, Hamadan University of Medical Sciences (No. 9904242478).

\section{Ethical Statement}

This study has been ethically approved by the ethics committee of Hamadan University of Medical Sciences (code number: IR.UMSHA.REC.1399.354).

\section{Conflict of Interests}

The authors declare that they have no competing interests.

\section{References}

1. World Health Organization. WHO Coronavirus Disease (COVID-19) Dashboard. 2020.Available from: https://covid19.who.int/?gclid= CjwKCAjw9vn4BRBaEiwAh0muDPMCzPiWetlLMk-AufUoH RXi qX-trDQUQuKz0gmpLNccwL6-2vSgRoCTS8QAvD_BwE

2. Peeri NC, Shrestha N, Rahman MS, Zaki R, Tan Z, Bibi S, et al. The SARS, MERS and novel coronavirus (COVID-19) epidemics, the newest and biggest global health threats: what lessons have we learned? Int J Epidemiol. 2020. Available from: https://academic.oup.com/ije/article/doi/10.1093/ije/dyaa033/5748175

3. Torales J, O'Higgins M, Castaldelli-Maia JM, Ventriglio A. The outbreak of COVID-19 coronavirus and its impact on global mental health. Int J Soc Psychiatry. 2020;66(5):317-320.

4. Wang W, Tang J, Wei F. Updated understanding of the outbreak of 
2019 novel coronavirus (2019-nCoV) in Wuhan, China. J Med Virol. 2020;92(4):441-7.

5. Haghani M, Bliemer MC, Goerlandt F, Li J. The scientific literature on Coronaviruses, COVID-19 and its associated safety-related research dimensions: A scientometric analysis and scoping review. Saf Sci. 2020;129.

6. Homolak J, Kodvanj I, Virag D. Preliminary analysis of COVID-19 academic information patterns: a call for open science in the times of closed borders. Scientometrics. 2020:1-15.

7. Lee JJ, Haupt JP. International Research Collaborations on COVID-19 Amidst Geopolitical Tensions with China. 2020. Available from: https://assets.researchsquare.com/files/rs-37599/v1/007e4d27-b3934ac2-9d4e-b3ab97fcbd49.pdf

8. Haghani M, Bliemer MC. Covid-19 pandemic and the unprecedented mobilisation of scholarly efforts prompted by a health crisis: Scientometric comparisons across SARS, MERS and 2019-nCov literature. arXiv preprint arXiv:200600674. 2020. Available from: https://arxiv.org/abs/2006.00674

9. Chahrour M, Assi S, Bejjani M, Nasrallah AA, Salhab H, Fares M, et al. A bibliometric analysis of Covid-19 research activity: A call for increased output. Cureus. 2020;12(3).

10. Aristovnik A, Ravšelj D, Umek L. A Bibliometric Analysis of COVID-19 across Science and Social Science Research Landscape. Sustainability. 2020;12(9132).

11. Horbach SP. Pandemic Publishing: Medical journals drastically speed up their publication process for Covid-19. bioRxiv. 2020 Available from: https://www.biorxiv.org/content/10.1101/2020.04.18. 045963v1.abstract

12. Kokol P, Blažun Vošner H, Završnik J. Application of bibliometrics in medicine: a historical bibliometrics analysis. Health Info Libr J. 2020. Available from: https://onlinelibrary.wiley.com/doi/abs/ 10.1111/hir.12295

13. Chen C. Information visualisation and virtual environments: Springer Science \& Business Media; 2013.

14. Dong M, Cao X, Liang M, Li L, Liang H, Liu G. Understand research hotspots surrounding COVID-19 and other coronavirus infections using topic modeling. medRxiv. 2020.

15. El Mohadab M, Bouikhalene B, Safi S. Bibliometric method for mapping the state of the art of scientific production in Covid-19. Chaos Solitons Fractals. 2020;139.

16. Lou J, Tian SJ, Niu SM, Kang XQ, Lian HX, Zhang LX, et al. Coronavirus disease 2019: a bibliometric analysis and review. Eur Rev Med Pharmacol Sci. 2020;24(6):3411-21.

17. Sivankalai S, Badhusha KN. Bibliometric study on COVID 19 Outbreak. 2020;10(2).

18. Zhai F, Zhai Y, Cong C, Song T, Xiang R, Feng T, et al. Research Progress of Coronavirus Based on Bibliometric Analysis. Environ Sci Pollut Res Int. 2020;17(11):3766.

19. Dehghanbanadaki H, Seif F, Vahidi Y, Razi F, Hashemi E, Khoshmirsafa $\mathrm{M}$, et al. Bibliometric analysis of global scientific research on Coronavirus (COVID-19). Med J Islam Repub Iran. 2020;34(1):354-62.

20. Colavizza G, Costas R, Traag VA, Van Eck NJ, Van Leeuwen T, Waltman L. A scientometric overview of CORD-19. BioRxiv. 2020. doi.org/10.1101/2020.04.20.046144

21. Singh S, Soni VM, Munjal N. Conceptual Structure and Perspectives on Corona Virus Research: A Bibliometric Study. Purakala. 2020;31(28):78-82.

22. Liu N, Chee ML, Niu C, Pek PP, Siddiqui FJ, Ansah JP, et al. Coronavirus Disease 2019 (COVID-19): An Evidence Map of Medical Literature. medRxiv. 2020. Available from: https://www.medrxiv.org/content/medrxiv/early/2020/05/11/2020.05.0 7.20093674.full.pdf

23. Kambhampati SB, Vaishya R, Vaish A. Unprecedented surge in publications related to COVID-19 in the first three months of pandemic: A bibliometric analytic report. J Clin Orthop Trauma. 2020;11(Suppl 3):S304-306.

24. Hu Y, Chen M, Wang Q, Zhu Y, Wang B, Li S, et al. From SARS to COVID-19: A bibliometric study on emerging infectious diseases with natural language processing technologies. 2020. Avaliable from: https://scholar.google.com/scholar?cluster=12589592972349817306\& $\mathrm{hl}=$ fa\&as_sdt $=0,5$

25. Kagan D, Moran-Gilad J, Fire M. Scientometric trends for coronaviruses and other emerging viral infections. BioRxiv. 2020. doi.org/10.1101/2020.03.17.995795
26. Patil S. A Scientometric Analysis of Global COVID-19 Research Based on Dimensions Database. 2020. Available from: doi.org/10.2139/ssrn.3631795

27. Laksham S, Surulinathi M, Balasubramani R, Srinivasaragavan S Mapping the Research output on Coronavirus: A Scientometric Study. Ged Org Rev. 2020;33(2):163-186.

28. Hossain MM. Current status of global research on novel coronavirus disease (Covid-19): A bibliometric analysis and knowledge mapping. Available from: https://papers.ssrn.com/sol3/Papers.cfm?abstract_id= 3547824.

29. Golinelli D, Nuzzolese AG, Boetto E, Rallo F, Greco M, Toscano F, et al. The impact of early scientific literature in response to COVID19: a scientometric perspective. medRxiv. 2020. Available from:https://www.medrxiv.org/content/10.1101/2020.04.15.20066183 v1.abstract

30. Joshua V, Sivaprakasam S. Coronavirus: Bibliometric analysis of scientific publications from 1968 to 2020. Med J Islam Repub Iran. 2020;34(1):456-63.

31. Tao Z, Zhou S, Yao R, Wen K, Da W, Meng Y, et al. COVID-19 will stimulate a new coronavirus research breakthrough: a 20 -year bibliometric analysis. Ann Transl Med. 2020;8(8).

32. Zhou Y, Chen L. Twenty-Year Span of Global Coronavirus Research Trends: A Bibliometric Analysis. Int J Environ Res Public Health. 2020;17(9):3082.

33. Radanliev P, De Roure D, Walton R, Van Kleek M, Santos O, Montalvo RM, et al. What country, university or research institute, performed the best on COVID-19? Bibliometric analysis of scientific literature. arXiv preprint arXiv:200510082. 2020. Available from: https://arxiv.org/abs/2005.10082

34. Belli S, Mugnaini R, Baltà J, Abadal E. Coronavirus mapping in scientific publications: when science advances rapidly and collectively, is access to this knowledge open to society? Scientometrics. 2020. doi.org/10.21203/rs.3.rs-29397/v1

35. Hamidah I, Sriyono S, Hudha MN. A Bibliometric Analysis of Covid-19 Research using VOSviewer. Indones J Sci Technol. 2020;5(2):34-41.

36. Le Bras P, Gharavi A, Robb DA, Vidal AF, Padilla S, Chantler MJ. Visualising COVID-19 Research. arXiv preprint arXiv:200506380. 2020. Available from: https://pureapps2.hw.ac.uk/ws/portalfiles/ portal/41094547/2005.06380v2.pdf

37. Vasantha RN, Patil S. Indian Publications on SARS-CoV-2: A bibliometric study of WHO COVID-19 database. Diabetes Metab Syndr. 2020;14(5): 1171-1178.

38. Fiesco-Sepúlveda KY, Serrano-Bermúdez LM. Contributions of Latin American researchers in the understanding of the novel coronavirus outbreak: a literature review. PeerJ. 2020;8:e9332.2020.

39. Ghadir MR, Ebrazeh A, Khodadadi J, Zamanlu M, Shams S, Nasiri M, et al. The COVID-19 Outbreak in Iran; The First Patient with a Definite Diagnosis. Arch Iran Med. 2020;23(7):503-4.

40. Sweileh WM. A bibliometric analysis of global research output on health and human rights (1900-2017). Glob Health Res Policy. 2018;3(1):30. doi.org/10.1186/s41256-018-0085-8

41. AlRyalat SAS, Malkawi LW, Momani SM. Comparing bibliometric analysis using PubMed, Scopus, and Web of Science databases. J Vis Exp. 2019(152):e58494. doi: 10.3791/58494

42. Van Eck NJ, Waltman L. Software survey: VOSviewer, a computer program for bibliometric mapping. Scientometrics. 2010;84(2):52338.

43. Chen Y, Guo YB, Guo R, Chen XF, Chang GH, Li X, et al. Visual analysis of coronavirus disease 2019 (COVID-19) studies based on bibliometrics. Zhongguo Zhong Yao Za Zhi. 2020;45(10):2239-48. 